ORIGINAL RESEARCH PAPER

\title{
DEGRADATION KINETICS OF COLOR, ANTIOXIDANT ACTIVITY, TOTAL PHENOLIC CONTENT, AND PHYSICOCHEMICAL INVESTIGATION OF BLANCHED AMARANTHUS LEAVES PUREE BY FTIR
}

\author{
JAGAMOHAN MEHER $^{* 1}$, RAJANANDINI MEHER ${ }^{2}$ \\ ${ }^{I}$ Department of Agricultural Engineering, Kalasalingam Academy of Research Education, \\ Krishnankoil, Sriviliputhur Tamil Nadu-626126, India, phone number: 7894916420 \\ ${ }^{2}$ Department of Biotechnology, Kalasalingam Academy of Research Education, Krishnankoil, \\ Sriviliputhur Tamil Nadu-626126, India, phone number: 6369804772 \\ *Corresponding author: jaga@klu.ac.in
}

Received on 29 March 2021

Revised on 17 August 2021

\begin{abstract}
The aim of the analysis was to find the optimal blanching period for Amaranthus tricolor leaves purees (ATP), that would result in the highest retention of total antioxidant activity (TAA), total polyphenol content (TPC), and chlorophyll (Chl) to boost their functional activity. ATP was blanched for 1, 3, 5, and 7 minutes at 70,80 , and $90^{\circ} \mathrm{C}$ for this analysis. The influence of blanching times on physicochemical, TAA, TPC, and Chl values was then studied. The unblanched and blanched puree was investigated using FTIR analysis $\left(90^{\circ} \mathrm{C}\right.$ for $\left.3 \mathrm{~min}\right)$. The variations in moisture content in ATP were not significant in the physicochemical analysis. There is a substantial decrease in ash content and a rise in $\mathrm{pH}$ value with increasing blanching time $(\mathrm{p}<0.05)$. As the blanching time for ATP was raised, the percent of the water-soluble index improved significantly $(\mathrm{p}<0.05)$. Content of TAA, TPC, and $\mathrm{Chl}$ in the ATP was steadily reduced as the blanching time was increased. The degradations of TAA, TPC, and Chl of ATP are well fit by firstorder kinetic models, with coefficient determination $\left(\mathrm{R}^{2}\right)$ ranging from $0.86-0.98$. The presence of ketone and alcohol is confirmed by the functional group obtained during the FTIR analysis of the sample. The results can promote household blanching as well as the food industry to prescribe a certain blanching period for vegetables to preserve their TAA, TPC, and Chl values.
\end{abstract}

Keywords: Amaranthus tricolor, antioxidant, polyphenol, chlorophyll, kinetics

https://doi.org/10.35219/foodtechnology.2021.2.03 


\section{Introduction}

Leafy vegetables are the primary natural source of food and human well-being, since the dawn of civilization. Only a few species (15 species) have been used extensively to meet human food requirements and provide a global energy supply (Maundu, 1996). Amaranthus tricolor (Elephant-Head Amaranth) is a characteristic green leafy vegetable plant that belongs to the Amaranthaceae family. A. tricolor has a variety of leaf colors, including white (light green), dark green, red, and purple, with red plants having more pigment than green ones. It grows in the summer in tropical areas around the world, including India, Africa, Bangladesh, Sri Lanka, and the Caribbean, and is often eaten as a vegetable by families (Magazù et al., 2008). It contains a lot of leaf pigments, carotene, trace elements (foliate, calcium, iron, and phosphorus), and essential nutrients (carbohydrate, protein, and vitamins) (Igbokwe and Hollins, 2000). It is a nutritious green vegetable that is used in stir-fries, soups, gravies, simmering dinners, daal, and curries in India, Bangladesh, and Sri Lanka.

The demand for processed food is rising in response to the increased population and fast-paced lifestyle. Because of the high nutritious content, affordability, and abundance of Amaranthus leaves around the world, there is a greater demand for their processing. Since most leafy vegetables are heat sensitive and low in calories, they are often eaten raw in salad form as well as after thermal processing. Since Raw vegetable consumption has been linked to the spread of infectious diseases due to their complex surface and porosity, which facilitate pathogen adhesion and survival, hence, most vegetables are consumed after limited processing (Bernhardt and Schlich, 2006). The nutrient content and phenolic compound of the food change significantly during the water blanching operation (del Pilar RamírezAnaya et al., 2015).

Blanching is a unit operation that involves heating fruits or vegetables to inactivate natural/endogenous enzymes, change the texture, preserve color, flavor, and nutritional value, and remove trapped air before freezing, canning, or drying. The hydrothermal treatment of blanching is used to extend the shelf life of vegetables. All vegetables must be blanched before being processed, as this helps to retain and improve the natural flavor, texture, and color of the fruits and vegetables (Oboh, 2005). Despite the necessity of blanching, it is only possible to blanch successfully if the blanching time is set correctly. Hence, it has been demonstrated that blanching vegetables at low temperatures for extended periods followed by high temperatures for a short amount of time reduces vegetable texture degradation and removes unwanted enzymes. Similarly, under-blanching and over-blanching cause the loss of flavor, color, and vitamins of leafy vegetables.

Blanching can be performed by hot water, steam, and the microwave. Water blanching is the easiest and successful method for vegetables. Blanching is carried out by immersing the vegetables in hot water or exposing them to open steam. Although its main objective is to inactivate certain enzymes responsible for the degradation of pigments and quality of vegetables. This technique is used to reduce the bitterness and acid component of the vegetable present in the leaves 
(Akindahunsi and Oboh, 2004). Blanching has additional desirable effects such as enhancing the color, expelling air from the tissue, and cleaning the surface.

As color is a major sensory characteristic in determining the product acceptability and quality of green vegetables, several attempts have been made to stabilize the green colour (Ihl et al., 1998). Thermal processing (like boiling and cooking) is one of the most widely used methods for prolonging the shelf life of foods, but it has a drawback when it comes to green leaf preservation because thermally treated green vegetables have a poorer color than fresh ones. The thermal treatment causes color changes (from bright green to olive-brown) during processing due to the conversion of chlorophylls to pheophytins (Ihl et al., 1998).

During the blanching of this ATP at high temperatures, there were chances of loss of some valuable compounds. To predict losses/gain, the knowledge of kinetics including reaction order and rate constant is very vital, especially during thermal processing. Kinetic models are used for fast quality assessment and prediction ATP; besides, they can be employed to predict the influence of processing on critical quality parameters. Data on the effects of blanching on color, nutrition, total phenol content, and antioxidant properties as well as a kinetic model of blanched vegetables are still limited. A more integrated analysis is needed to obtain insight into the effects of aqua thermal processing in blanching on the antioxidant capacity of commonly consumed vegetables. Therefore, the purpose of this study is to investigate the effects of water blanching time on physicochemical, color, antioxidant activity, and total phenolic content of commonly consumed ATP in India.

\section{Materials and methods}

\section{Blanching and its assessment}

Fresh Amaranthus leaves were obtained from a local market in Raipur, Chhattisgarh (India). The blanching was conducted in an open container (water bath, Remi India Ltd., Model No-RSB-12) for the specified time (1, 3, 5, and 7 min) and temperature $\left(70,80\right.$, and $\left.90^{\circ} \mathrm{C}\right)$. Both physical operations (blanching and mixing) were carried out at room temperature, confirming the assumption of no pigment evaporation (Kao et al., 2014). To avoid water loss due to evaporation, the water bath was sealed. Ten grams of ATP were blanched separately for the desired temperature, duration and then cooled immediately by dipping in cold water $\left(10^{\circ} \mathrm{C}\right)$. The cooled leaves were ground for 3 mins using a wet grinder (Bajaj India, model-WX 3, $140 \mathrm{rpm})$ with the addition of purified water $(150 \mathrm{ml} / \mathrm{kg}$ of leaves) after extracting the excess water. As a control, samples that were blanched for 0 minutes were used. The samples were then vacuum sealed and stored in polyethylene bags in the refrigerator at $4^{\circ} \mathrm{C}$ for 24 hours. The determination of antioxidant activity, chlorophyll, total phenolic content, and physicochemical analysis were carried within 24 hours after blanching. The ground material was filtered through Whatman filter paper $(125 \mathrm{~mm})$ and was tested for peroxidase activity. A volume of $5 \mathrm{~mL}$ extract was taken in a test tube containing $1 \mathrm{~mL}$ 
guaiacol solution $(0.5 \%$ in ethanol) and $1 \mathrm{~mL}$ hydrogen peroxide $(0.03 \%)$. Blanching was considered to have been achieved by visual observation (no bubble evolution and no color change in the subsequent samples) (Peroxidase activity).

\section{Physiochemical analyses}

To determine the initial moisture, ash, $\mathrm{pH}$, and chlorophyll content of the puree, physicochemical analysis was performed using different standard procedures, as described below.

\section{Extraction and estimation of Chlorophyll}

The color is an important quality indicator of food and defines the customer acceptability of the food product. Chlorophyll content was analyzed using the method described by Armon (1949). One gram of fresh leaf material was taken and homogenized in a mortar and pestle with $20 \mathrm{ml}$ of $80 \%$ acetone. The homogenate was centrifuged (Remi India, Model No-R-8C DX) at 10,000 rpm for 10 minutes. The residue was re-extracted with $10 \mathrm{ml}$ of $80 \%$ acetone. The total chlorophyll content $(\mu \mathrm{g} / \mathrm{gm})$ of Amaranthus leaves was calculated using absorbance measurements at $663 \mathrm{~nm}$ for chlorophyll $a$ and $645 \mathrm{~nm}$ for chlorophyll $b$. The colour of the puree was determined before and after treatment by a UV spectrophotometer (Systronics, India). Instrumental color analysis using the UV spectrophotometer provides an objective way to quantitatively measure and compare the color of food samples, by standardizing the elements necessary to view color. The following calculations were used to ascertain sample chlorophyll concentrations.

$$
\begin{aligned}
& \text { Chlorophyll } a\left(\frac{m g}{m L}\right)=12.7 A 663-2.69 A 645 \\
& \text { Chlorophyll } b\left(\frac{m g}{m L}\right)=22.9 A 645-4.68 A 663 \\
& \text { Total Chlorophyll }\left(\frac{m g}{m L}\right)=\text { Chlorophyll } a+\text { Chlorophyll b }
\end{aligned}
$$

where: A645 = absorbance at a wavelength of $645 \mathrm{~nm}$; A663 = absorbance at a wavelength of $663 \mathrm{~nm}$.

\section{Ash content determination}

Three grams of the sample was weighed in a crucible, heated in a muffle furnace at $823 \mathrm{~K}$ for $30 \mathrm{~min}$, and cooled in desiccators. The ash content was calculated using the following equation (Manzi et al., 2001).

$$
\% \text { Ash }(\text { wetbasis })=\frac{M_{\text {ash }}}{M_{\text {wet }}} \times 100
$$

where: $M_{a s h}=$ mass of ash sample and $M_{w e t}=$ mass of the wet sample.

\section{pH measurements}

The $\mathrm{pH}$ of the puree was measured using a $\mathrm{pH}$ meter (Eutech instrument, Singapore). Adjustment of $\mathrm{pH}$ was done using a buffered solution by combining 
$0.1 \mathrm{M}$ citric with $0.2 \mathrm{M}$ disodium hydrogen phosphate (Mcllvaine's buffer) to the desired $\mathrm{pH} \pm 0.05$. The $\mathrm{pH}$ electrode was rinsed with distilled water and then with the buffer for calibration (i.e. $\mathrm{pH}$ 7.00). After calibration, the $\mathrm{pH}$ electrode was again rinsed with distilled water to prevent carryover contamination of the tested solutions. The electrode was gently bolted on a laboratory cleaning tissue to remove the excess rinse water. The $\mathrm{pH}$ electrode was dipped into the puree sample. The $\mathrm{pH}$ was recorded at $30^{\circ} \mathrm{C}$ when the $\mathrm{pH}$ reading was stable (Koca et al., 2007).

\section{Quantification of water solubility index (WSI)}

WSI was determined according to Yağcı and Göğüş (2008). A total of $10 \mathrm{~g}$ of the sample was boiled into $200 \mathrm{~mL}$ of distilled water. This solution was transferred to some experimental tubes, centrifuged at $3000 \mathrm{rpm}$ for $5 \mathrm{~min}$, and allowed to settle completely for $30 \mathrm{~min}$. An aliquot of $25 \mathrm{~mL}$ of the supernatant was transferred to pre-weighed Petri dishes and immediately oven-dried at $105^{\circ} \mathrm{C}$ for $5 \mathrm{~h}$. The water solubility index (WSI) was calculated as the weight difference by following equation 5.

$$
W S I \%=\frac{\text { Weight of dissolved solid in supernatant }}{\text { weight of dry solids }} \times 100
$$

\section{DPPH Antioxidant Activity}

The total antioxidant activity (TAA) was determined by the 2,2-diphenyl-1picrylhydrazyl (DPPH) method. In brief, $100 \mu$ l of the sample was mixed with $3900 \mu \mathrm{l}$ of $0.1 \mathrm{mM}$ freshly prepared DPPH solutions and the samples were incubated in dark at room temperature for 30 minutes. The absorbance was taken for each sample at a wavelength of $517 \mathrm{~nm}$. Ascorbic acid was considered as standard and the antioxidant activity was calculated according to equation 6 .

$$
\text { Total Antioxidant Activity }(\%)=\frac{\mathrm{Abs}_{\mathrm{control}-\mathrm{Abs}_{\text {sample }}}}{\mathrm{Abs}_{\mathrm{control}}} \times 100
$$

\section{Total Phenolic Content (TPC)}

The total phenolic content of the beverage samples was determined by the Folin Ciocalteau method. In brief, $200 \mu 1$ of the sample was mixed with $1720 \mu 1$ of Merck Millipore water, $80 \mu \mathrm{l}$ of Folin-Ciocalteau reagent was added to the solution and mixed thoroughly. $200 \mu \mathrm{l}$ of $20 \% \mathrm{Na}_{2} \mathrm{CO}_{3}$ was added further followed by the addition of $1800 \mu \mathrm{l}$ of water, to make up a volume of $4 \mathrm{ml}$. The absorbance reading was taken at $725 \mathrm{~nm}$ in the UV-VIS Spectrophotometer for each sample. Gallic acid was taken as standard and the TPC was calculated using a calibration curve of Gallic acid $(y=0.0003 x+0.0017)$. The results were expressed in terms of gallic acid equivalent.

\section{Kinetic analysis}

\section{Calculation of rate constants $(k)$ and half-life values $\left(t_{1 / 2}\right)$}

To predict the nutrient losses, the knowledge of kinetics including reaction order and rate constants is very vital, especially during thermal processing. Kinetic models are used for fast quality assessment and prediction; besides, they can be employed to predict the influence of processing on critical quality parameters. In this study, we investigated the effect of blanching in the percentage of loss and the 
first order of degradation kinetics of total polyphenol content (TPC), and DPPH Radical Scavenging Activity (RSA) of ATP. Thermal destruction of microorganisms, as well as nutrients, obey first-order kinetics (Musa et al. 2017).

$$
\frac{-d c}{d t}=k c
$$

Where dc/dt is the rate of decrease of concentration, c is existing concentration, and $\mathrm{k}$ is the first-order reaction rate constant. Integrating with limits $c_{l}$ at time $t_{l}$ and $c_{2}$ at time $t_{2}$,

$$
\log c_{2}=\log c_{1}-\frac{k\left(t_{2}-t_{1}\right)}{2.303}
$$

The temperature sensitivity of the kinetic parameter can be defined as the Arrhenius technique. The logarithm of the reaction rate constant $(k)$ is related to the reciprocal of the absolute temperature with activation energy $\left(E_{a}\right)$ representing the slope index of the semi-logarithmic curve. Temperature dependency of the reaction rate constant is predicted using Arrhenius law. To determine the temperature dependency of chlorophyll degradation in amaranth leaves puree, the logarithms of rate constants $(k)$ were plotted against $1 / T$ (where $\mathrm{T}$ is the temperature in $\mathrm{K}$ ). The slope of linear regression analysis resulted in the determination of activation energy $\left(E_{a}\right)$ after the slope is multiplied by $\mathrm{R}$ (where $\mathrm{R}$ is $8.314 \mathrm{~J} / \mathrm{mol} \mathrm{K}$ ).

$$
k=k_{0} \exp \left(-E_{a} / R T\right)
$$

where, $E_{a}=$ Activation energy; $R=$ Gas Constant; $k=$ Reaction Rate Constant at $T$ (abs. temp.) and $s=$ frequency factor

Half-life time is the time needed for $50 \%$ degradation of chlorophyll. It is calculated by using equation 10 .

$$
\mathrm{t}_{1 / 2}=-0.693 / \mathrm{k}
$$

\section{Statistical analysis}

The stability of chlorophyll during thermal degradation of the Amaranthus leaves was analyzed using a linear regression model to obtain the degradation rate constants $(\mathrm{k})$ and activation energy $(\mathrm{Ea})$. ANOVA and t-test were used to determine the mean differences. The significant difference was defined at $p<0.05$ with a 95\% level of confidence. The average value of all the experimental data was analyzed using statistical parameters including Root mean square error (RMSE) and coefficient of determination $\left(\mathrm{R}^{2}\right)$ were determined and were defined as,

$$
\begin{aligned}
& R M S E=\sqrt{\frac{\sum_{i=1}^{N}(E V-M V)^{2}}{N}} \\
& R^{2}=1-\frac{\sum_{i=1}^{N}(M V-E V)^{2}}{\sum_{i=1}^{N}\left(E V-E V_{\text {avg }}\right)^{2}}
\end{aligned}
$$


where $\mathrm{EV}$ is the experimental value, $\mathrm{MV}$ is the modeled value $\mathrm{EV}_{\text {avg }}$ is the average of the experimental value and $\mathrm{N}$ is the number of observations.

\section{Results and discussion}

\section{Effect of blanching on physicochemical properties of ATP}

The various physicochemical parameters of leaves, such as moisture content, $\mathrm{pH}$, ash content, and water solubility index, were determined in triplicate and average values are reported in Table 1. The knowledge of the physicochemical properties of leaves is desirable in determining the transport phenomenon of processed leaves in food industries, as these parameters are essential in solving transport equations. Moisture content gives information about the amount of water present in the leafy vegetable. The initial moisture content of the ATP was about $86.62 \%$ (wet basis), which increased to $90.27 \%$ after 7 mins of blanching (Table 1). The results depict that moisture content in ATP was not significantly changed by different blanching times. Whereas ash content was significantly decreased with increasing the blanching time in samples $(\mathrm{p}<0.05)$. The initial nutrient contents of ATP before blanching are shown in Table 1 (for Ash content value of 1.30\%). The high ash content in the sample is a reflection of mineral contents preserved in the leaf materials, which is decreased concerning blanching time, due to the leaching of the minerals. Hence, the water solubility index values increased from $1.69 \%$ to $16.69 \%$ concerning the duration of blanching from $1 \mathrm{~min}$ to $7 \mathrm{~min}$ respectively. The $\%$ of water solubility index increased with increasing blanching time in ATP. This finding may be due to the leaching of soluble sugars and organic acids into the water.

Table 1. Physicochemical Properties of blanched $\left(90{ }^{\circ} \mathrm{C}\right.$ for $\left.2 \mathrm{~min}\right)$ for Amaranthus Tricolor leaves.

\begin{tabular}{|c|c|c|c|c|c|}
\hline $\begin{array}{l}\text { Blanching } \\
\text { Time (min) }\end{array}$ & $\mathbf{0}$ & 1 & 3 & 5 & 7 \\
\hline $\begin{array}{l}\text { Moisture } \\
(\%)\end{array}$ & $86.62 \pm 1.9^{\mathrm{a}}$ & $92.23 \pm 2.2^{\mathrm{a}}$ & $91.32 \pm 2.4^{\mathrm{a}}$ & $90.46 \pm 2.57^{\mathrm{a}}$ & $90.27 \pm 2.64^{a}$ \\
\hline $\operatorname{Ash}(\%)$ & $1.30 \pm 0.01^{\mathrm{a}}$ & $0.95 \pm 0.01^{\mathrm{b}}$ & $0.92 \pm .01^{\mathrm{c}}$ & $0.90 \pm .01^{\mathrm{d}}$ & $0.85 \pm .01^{\mathrm{e}}$ \\
\hline pH & $6.08 \pm 0.04^{\mathrm{d}}$ & $6.85 \pm 0.01^{\mathrm{c}}$ & $7.45 \pm 0.05^{\mathrm{b}}$ & $7.45 \pm 0.07^{\mathrm{b}}$ & $7.50 \pm 0.04^{\mathrm{a}}$ \\
\hline WSI (\%) & --- & $1.69 \pm 0.27^{\mathrm{d}}$ & $3.45 \pm 0.92^{\mathrm{c}}$ & $6.61 \pm 1.45^{\mathrm{b}}$ & $16.69 \pm 3.13^{\mathrm{a}}$ \\
\hline $\begin{array}{l}\text { Chl } a \\
(\mu \mathrm{mol} / \mathrm{l})\end{array}$ & $11.30 \pm 0.14^{\mathrm{a}}$ & $10.05 \pm 0.13^{\mathrm{a}}$ & $9.02 \pm 0.05^{\mathrm{c}}$ & $7.08 \pm 0.17^{\mathrm{b}}$ & $6.07 \pm 0.04^{\mathrm{a}}$ \\
\hline $\begin{array}{l}\text { Chl } b \\
(\mu \mathrm{mol} / \mathrm{l})\end{array}$ & $4.69 \pm 0.11^{\mathrm{a}}$ & $3.01 \pm 0.24^{c}$ & $2.51 \pm 0.05^{\mathrm{b}}$ & $1.46 \pm 0.09^{\mathrm{b}}$ & $1.08 \pm 1.12^{\mathrm{a}}$ \\
\hline TAA $(\%)$ & $48.62 \pm 0.21^{\mathrm{b}}$ & $47.84 \pm 0.19^{\mathrm{a}}$ & $41.56 \pm 1.10^{\mathrm{b}}$ & $34.54 \pm 0.19^{c}$ & $31.25 \pm 0.21^{\mathrm{c}}$ \\
\hline $\begin{array}{l}\text { TPC (mg } \\
\text { GAE/100g) }\end{array}$ & $785 \pm 1.27^{\mathrm{a}}$ & $725 \pm 1.35^{\mathrm{b}}$ & $650 \pm 1.22^{c}$ & $612 \pm 0.31^{b}$ & $557 \pm 2.17^{\mathrm{c}}$ \\
\hline
\end{tabular}

*Data from three repetitions with mean \pm S.D; means with different superscript letters $(a, b$, and c) in the same column were significantly different (ANOVA, $\mathrm{p}<0.05$ ). 
These findings are consistent with Patil et al. (2020) findings on the nutritional quality parameters of green leafy vegetables (roselle leaves, Fenugreek, and amaranth) The natural $\mathrm{pH}$ (6.08) of the ATP increased with the increase in blanching duration for a fixed temperature of $90^{\circ} \mathrm{C}$. Thus, ATP is less acidic. The $\mathrm{pH}$ value increased with increasing the duration of blanching time for ATP $(p<0.05)$. That may be occurred because of the release of ascorbic acid due to cell disintegration and the destruction of it during blanching (Oyetade et al., 2012).

\section{Fourier Transform Infrared (FTIR) analysis of an unblanched and blanched ATP}

The complex formation in extractants of an unblanched and blanched sample of amaranth leaves puree was examined using FTIR analysis. IR spectroscopy was used to investigate the functional groups present in the extractant of the leaves. Figure 1 illustrates the spectra of an unblanched and blanched sample of amaranth leaves puree sample. In an investigation of the characteristics of the ketone group by IR spectroscopy, two of the most useful peaks are found in an unblanched sample of amaranth leaves puree at $1690-1760 \mathrm{~cm}^{-1}$ of $\mathrm{C}=\mathrm{O}$ stretch of carboxylic acids and 3200-3500 $\mathrm{cm}^{-1}$ of O-H stretch, H-bonded. Similarly, for the blanched sample, the same spectra were obtained at $3200-3500 \mathrm{~cm}^{-1}$ of $\mathrm{O}-\mathrm{H}$ stretch, $\mathrm{H}-$ bonded, and $1690-1760 \mathrm{~cm}^{-1}$ of $\mathrm{C}=\mathrm{O}$ stretch of carboxylic acids. The functional group obtained during the analysis of the sample signifies the presence of the ketone and alcohol groups. No such differences of functional groups were found in blanched as well as unblanched puree samples. In all the cases acetone was used as an extractant hence peak in the range of $1660-1760 \mathrm{~cm}^{-1}$ was observed in all the samples. Similarly, FTIR spectra of the Aloe vera suspension in the polysaccharides region of (1200-800 $\left.\mathrm{cm}^{-1}\right)$ were reported (Opazo-Navarrete et al., 2012). In the region of (1200-1000 $\left.\mathrm{cm}^{-1}\right)$ on increasing the absorption, stretching vibrations of $(\mathrm{C}-\mathrm{OH})$ group and $(\mathrm{C}-\mathrm{O}-\mathrm{C})$ bond were observed. This data could be helpful in the researchers working in the field of food science to understand the nature of the puree and correlate it to the chemistry behind the effect of heat on the purees.

\section{Thermal degradation studies during blanching and kinetics determination}

To determine the degradation rate of colour during blanching, the study was conducted at a blanching temperature of $70-90^{\circ} \mathrm{C}$ for $3 \mathrm{~min}$ on ATP leaves (Table 3). The kinetics of thermal degradation was investigated and the degradation equation was observed to be first order. Normalized concentration $\left(\ln C / C_{0}\right)$ was plotted against time to determine the first-order rate constant. System variables (temperature) were observed to influence the degradation rate constant. It was found that, as the temperature is raised from $70^{\circ} \mathrm{C}$ to $90^{\circ} \mathrm{C}$, there has been a uniform increase in $k$ values of both Chl $a$ and $\mathrm{Chl} b$ of ATP (Table 3). For amaranth leaves puree rate constant for $\mathrm{Chl} a$ increase from 0.0671 to $0.0914 \mathrm{~min}^{-1}$ at $6.6 \mathrm{pH}$ as temperature increases from $70^{\circ} \mathrm{C}$ to $90^{\circ} \mathrm{C}$ (Figure 2). Similarly, for $\mathrm{Chl} b$, the values increase from 0.0674 to $0.2004 \mathrm{~min}^{-1}$ at $\mathrm{pH} 6.6$ as the temperature was raised from $70^{\circ} \mathrm{C}$ to $90^{\circ} \mathrm{C}$ (Figure 2). An increase in $k$ values with an increase in temperature represents the higher degradation of chlorophyll at a higher temperature. A higher decrease of 
$k$ value was observed for $\mathrm{Chl} b$ than $\mathrm{Chl} a$. This signifies that $\mathrm{Chl} b$ is more susceptible to heat treatment than Chl $a$ (Schwartz and Von Elbe, 1983).

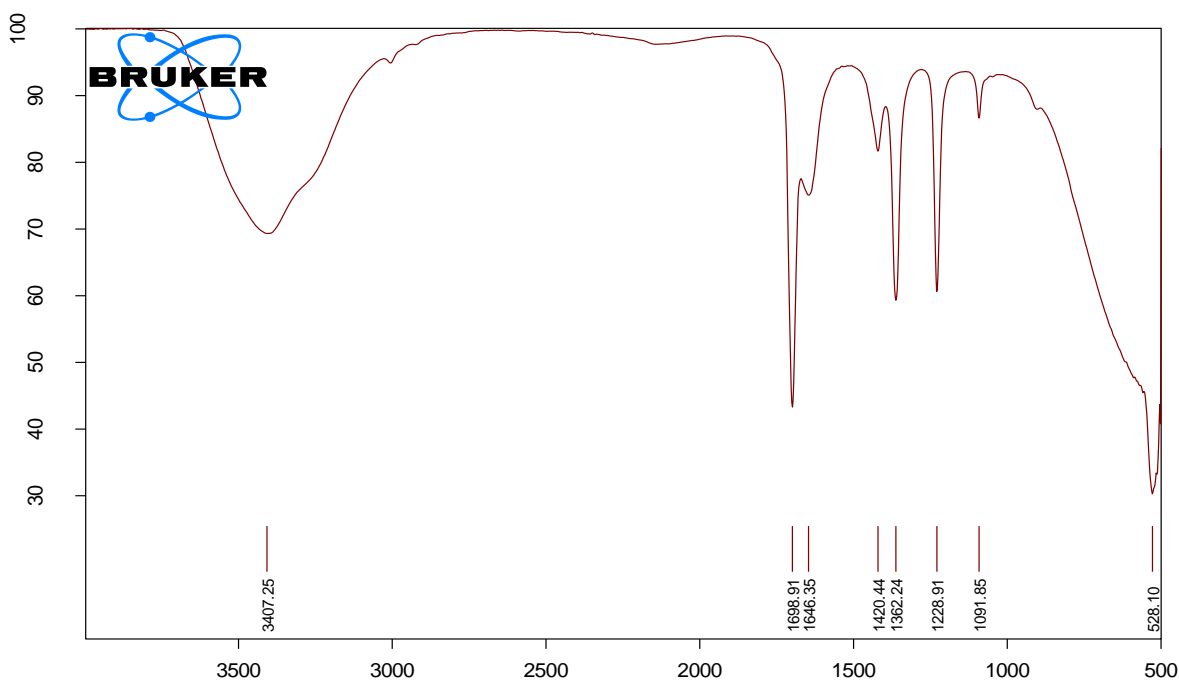

(a)

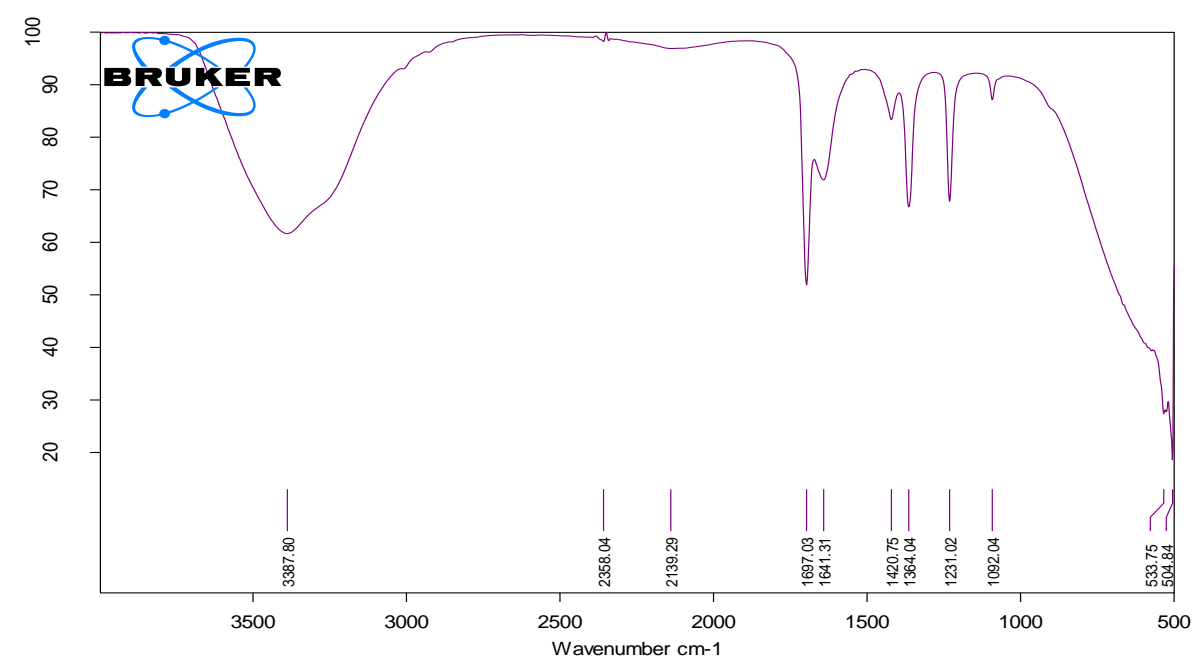

(b)

Figure 1. FTIR spectra of (a) unblanched (b) blanched amaranth leave puree extractant.

In the case of the degradation of Chlorophyll, it is expected that the color of puree changes to slightly yellowish. However, the difference is not very large and a uniform and almost equal degradation of both chlorophyll molecules occur, so the color changes from dark green to light green. Though it is recommended to apply strong thermal treatment to achieve commercial sterility, it is noticed that this leads to higher color degradation. 
Table 2. The percentage of loss, Kinetic parameters for chlorophyll a, chlorophyll b, TAA, TPC, and statistical values of first-order models of Red Amaranth leaves.

\begin{tabular}{|c|c|c|c|c|}
\hline \multicolumn{2}{|c|}{ Parameters } & \multicolumn{3}{|c|}{ Temperatures } \\
\hline & & $70^{\circ} \mathrm{C}$ & $80^{\circ} \mathrm{C}$ & $90^{\circ} \mathrm{C}$ \\
\hline \multirow{4}{*}{$\begin{array}{l}\text { The percentage } \\
\text { of Loss }(\%) \text { after } \\
\text { 3min of } \\
\text { blanching }\end{array}$} & TAA & 8.153 & 11.334 & 14.516 \\
\hline & TPC & 7.00 & 8.917 & 17.197 \\
\hline & Chlorophyll a & 10.444 & 15.752 & 20.177 \\
\hline & Chlorophyll b & 15.778 & 42.388 & 46.43 \\
\hline \multirow[t]{6}{*}{ Chlorophyll a } & $k \pm$ s.d. $\left(\mathrm{min}^{-1}\right)$ & $0.067 \pm 0.001$ & $0.078 \pm 0.007$ & $0.091 \pm 0.005$ \\
\hline & $\mathbf{t}_{1 / 2} \pm$ s.d. (min) & $10.32 \pm 0.11$ & $8.81 \pm 0.16$ & $7.58 \pm 0.33$ \\
\hline & $E_{a}(\mathrm{~kJ} / \mathrm{mol})$ & & $15.99 \pm 0.25$ & \\
\hline & $\mathbf{R}^{2}$ & 0.981 & 0.975 & 0.962 \\
\hline & RMSE & 0.003 & 0.001 & 0.003 \\
\hline & $k \pm$ s.d. $\left(\mathrm{min}^{-1}\right)$ & $0.067 \pm 0.001$ & $0.125 \pm 0.02$ & $0.200 \pm 0.05$ \\
\hline \multirow[t]{4}{*}{ Chlorophyll b } & $\mathbf{t}_{1 / 2} \pm$ s.d. $(\mathrm{min})$ & $10.28 \pm 0.11$ & $5.53 \pm 0.25$ & $3.45 \pm 0.19$ \\
\hline & $E_{a}(\mathbf{k J} / \mathbf{m o l})$ & & $56.45 \pm 0.16$ & \\
\hline & $\mathbf{R}^{2}$ & 0.964 & 0.981 & 0.974 \\
\hline & RMSE & 0.005 & 0.001 & 0.002 \\
\hline \multirow[t]{5}{*}{ TAA } & $k \pm$ s.d. $\left(\mathrm{min}^{-1}\right)$ & $0.037 \pm 0.01$ & $0.048 \pm 0.05$ & $0.067 \pm 0.12$ \\
\hline & $\mathbf{t}_{1 / 2} \pm$ s.d. (min) & $18.48 \pm 0.12$ & $14.43 \pm 0.05$ & $10.20 \pm 0.12$ \\
\hline & $E_{a}(\mathrm{~kJ} / \mathbf{m o l})$ & & $1.56 \pm 0.35$ & \\
\hline & $\mathbf{R}^{2}$ & 0.975 & 0.963 & 0.982 \\
\hline & RMSE & 0.001 & 0.003 & 0.001 \\
\hline \multirow[t]{5}{*}{ TPC } & $k \pm$ s.d. $\left(\mathrm{min}^{-1}\right)$ & $0.029 \pm 0.001$ & $0.038 \pm 0.001$ & $0.046 \pm 0.002$ \\
\hline & $\mathbf{t}_{1 / 2} \pm$ s.d. (min) & $23.65 \pm 0.27$ & $18.09 \pm 0.18$ & $14.77 \pm 0.21$ \\
\hline & $E_{a}(\mathbf{k J} / \mathbf{m o l})$ & & $0.91 \pm 0.15$ & \\
\hline & $\mathbf{R}^{2}$ & 0.965 & 0.965 & 0.982 \\
\hline & RMSE & 0.001 & 0.006 & 0.001 \\
\hline
\end{tabular}

All values are of means of triplicate determination expressed on wet weight basis \pm standard deviation. RMSE $=$ Root mean square error .

Thermal destruction of microorganisms, as well as nutrients, complies with firstorder kinetics (Jaiswal et al., 2012) described in Eq. (7). Kinetic parameters $\left(k, E_{a}\right)$ are useful to predict the quantity change that occurs during thermal processing. The lower the value of $k$, the better is the stability of colour. Higher is the $E_{a}$ value, greater is the heat sensitivity of visual colour degradation during thermal processing. It has been found that the activation energies of both $\mathrm{Chl} a$ and $\mathrm{Chl} b$ are comparable. Activation energies of amaranth leave puree at $\mathrm{pH} 6.6$ for $\mathrm{Chl} a$ was $15.99 \pm 0.25 \mathrm{~kJ} / \mathrm{mol}$ and for $\mathrm{Chl} b$ were $56.45 \pm 0.16 \mathrm{~kJ} / \mathrm{mol}$. Table (3) reported the values of activation energy obtained for the purees. The values are in agreement with the work by Rudra et al. (2008), in the studies on the thermal degradation kinetics of chlorophyll in pureed coriander leaf at varying levels of $\mathrm{pH} 6.6$ and temperature $\left(80-140^{\circ} \mathrm{C}\right)$. Chlorophyll degradation followed first-order reaction kinetics with activation energies ranging from 6.57 to $96.00 \mathrm{~kJ} / \mathrm{mol}$. 
(a)

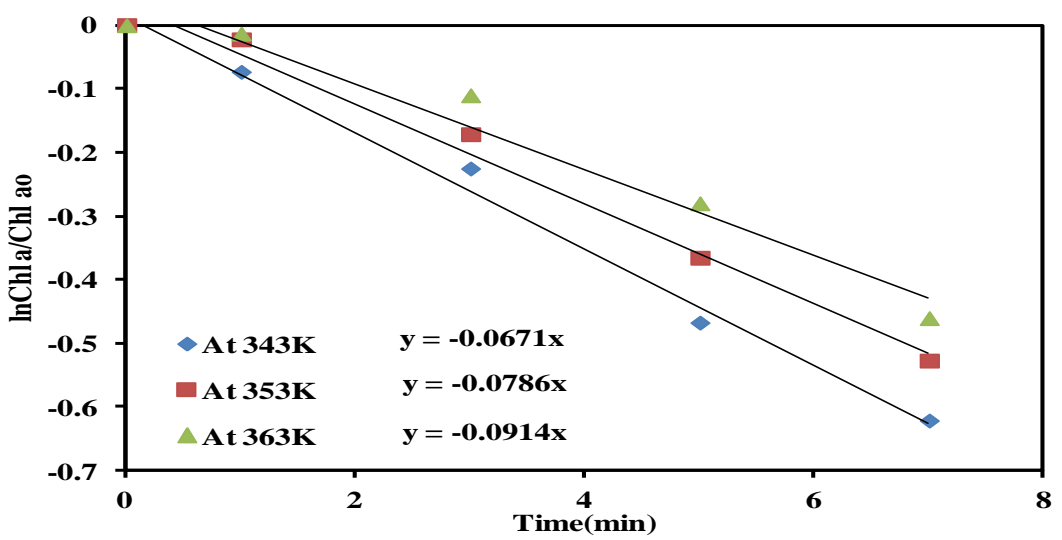

(b)

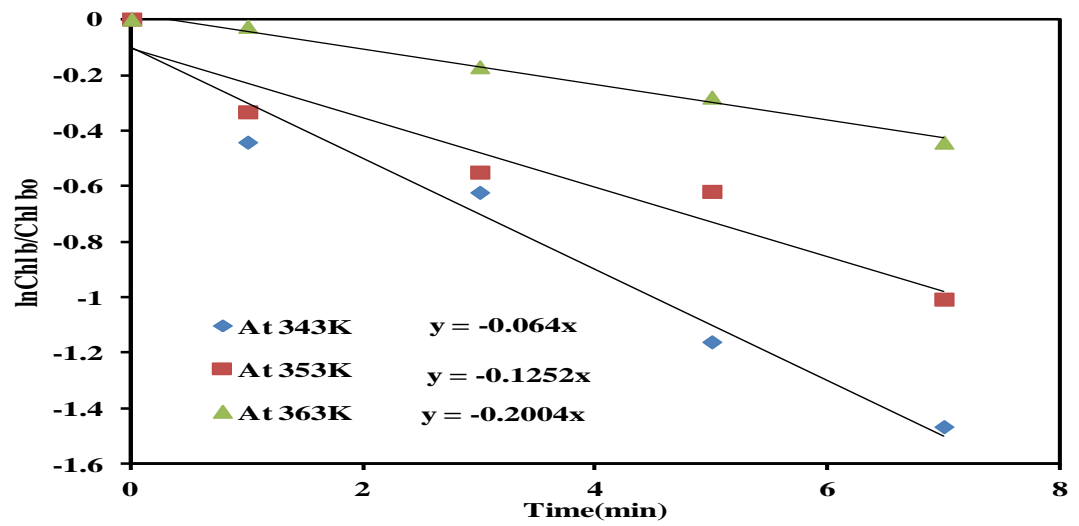

Figure 2. Thermal degradation of (a) chlorophyll $a$ (b) chlorophyll $b$ of amaranth leaves puree at 70,80 , and $90{ }^{\circ} \mathrm{C}$.

Jinasena et al. (2016) studied the degradation of chlorophyll extracted from $A$. sessilis to be of first-order reaction model and the effect of temperature $\left(15-50^{\circ} \mathrm{C}\right)$ on the rate constant was also modeled by Arrhenius equations with an activation energy of chlorophyll $a$ and $b$ and was found to be $12.61 \mathrm{~kJ} / \mathrm{mol}$ and $11.63 \mathrm{~kJ} / \mathrm{mol}$ respectively. Thermal color degradation of African cowpea leaves during heat treatment of $55-80^{\circ} \mathrm{C}$ per $90 \mathrm{~min}$ was investigated by Wawire et al. (2016). Thermal degradation of the green color in the leaves is of first-order reaction kinetics followed by the Arrhenius equation having activation energy of $88.78 \pm 3.21 \mathrm{~kJ} / \mathrm{mol}$. Similarly, activation energy values of 23.33 and $18.65 \mathrm{~kJ} / \mathrm{mol}$ were reported for orange and tamarind juice concentrates (Manohar et al., 1991). A half lifetime of $\mathrm{Chl} a$ of amaranth leaves was found to decrease from 10.32 to 7.58 min as the temperature was raised from $70^{\circ} \mathrm{C}$ to $90^{\circ} \mathrm{C}$, for $\mathrm{pH}$ values of 6.6 . Thus, the degradation of $\mathrm{Chl} a$ is higher at a higher temperature.

\section{Effect of blanching time on total antioxidant activity (TAA)}

The total antioxidant activity was calculated using DPPH Radical Scavenging Activity (RSA) in this research. Table 2 summarizes the RSA levels in unblanched 
ATP leaves and their changes after blanching. In blanched ATP, RSA was found to have decreased over time. After 3 minutes of blanching, RSA in blanched ATP tissues was reduced to $41.56 \%$, down from $48.62 \%$ at the beginning. When the blanching period was increased to 7 minutes, the RSA reduced dramatically to $31.25 \%$ (Table 1). The degradation rate of TAA was calculated using a first-order kinetic model (Figure 3). With a temperature increase from $70^{\circ} \mathrm{C}-90^{\circ} \mathrm{C}$, the halflife of ATP was reduced from 18.48 minutes to 10.20 minutes (Table 2). According to Puupponen-Pimiä et al. (2003), the DPPH index of cauliflower decreased by $23 \%$ after blanching in water. The large surface area of the vegetables in contact with the water caused the loss of antioxidant activity in cooked tissue during blanching (Howard et al., 1999). After aqua thermal treatment of broccoli (Zhang et al., 2003) and other cruciferous vegetables, antioxidant levels were reported to decrease (Cieślik et al., 2007).

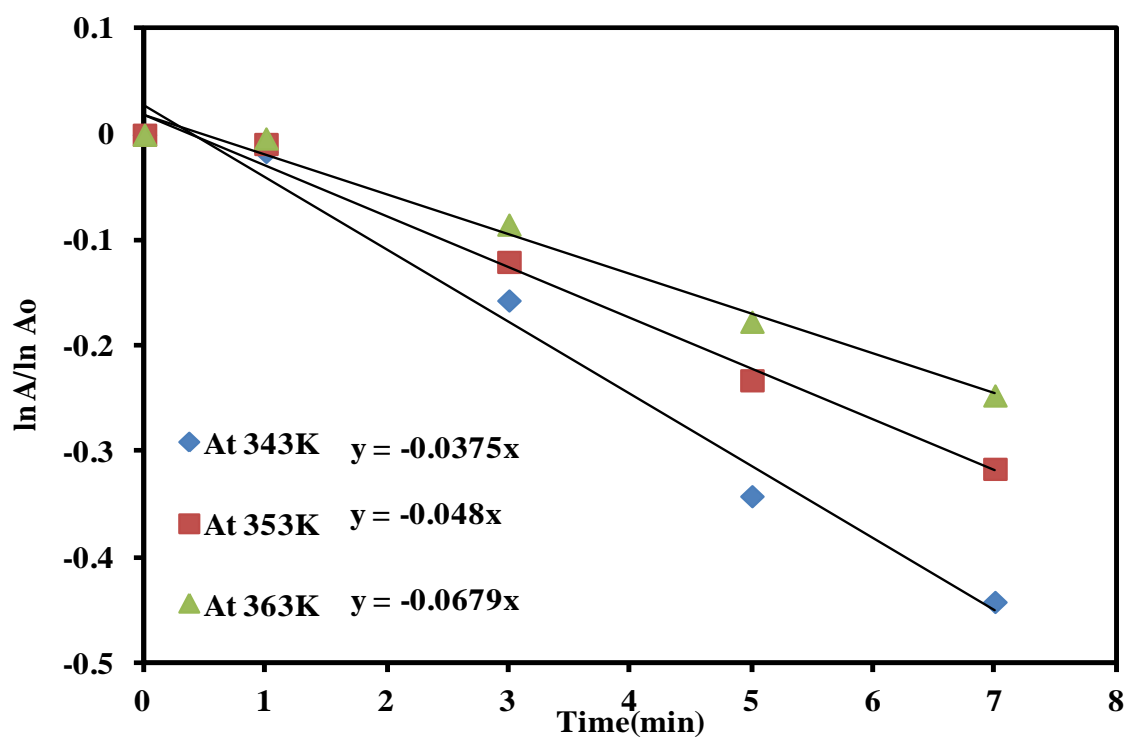

Figure 3. First-order kinetics model of total antioxidant activity of amaranth leaves puree at 70,80 , and $90^{\circ} \mathrm{C}$.

\section{The effect of blanching time on total polyphenol content (TPC)}

Figure 4 depicts the impact of blanching time on total phenolic contents of raw and blanched ATP, while Table 2 shows the percentage of losses. The TPC in ATP was found to decrease significantly $(\mathrm{p}<0.05)$ as the blanching period increased, with the loss at 3 minutes blanching was about $17.191 \%$ of the initial amount at $90^{\circ} \mathrm{C}$. Blanching opens the cell matrix, encourages complete photochemical extractability and bio-accessibility, promotes the release of bound photochemical, forms soluble low molecular weight photochemical that is easily degraded by the heating process, and decreases total phenolic content (Palermo et al., 2014). The first-order kinetic model for bioactive compound degradation during aqua thermal treatment was found to correlate with previous research (Nakilcioglu-Taş and Otleş, 2017). To test the relationship between blanching time and TPC compound degradation, a 
graph was plotted between blanching time and $C_{t} / C_{0}$ values (Figure 4). The puree's half-life time $\left(\mathrm{t}_{1 / 2}\right)$ was decreasing with increasing temperature, according to the $1 \mathrm{st}$ order kinetics model. After 3 minutes of blanching, TPC decreased by $17.197 \%$ from its initial amount of $90^{\circ} \mathrm{C}$ (Table 2). The graph's $\mathrm{R}^{2}$ value showed a strong correlation between the ATP expected value and experimental values, as well as a strong correlation between blanching time and TPC losses in ATP.

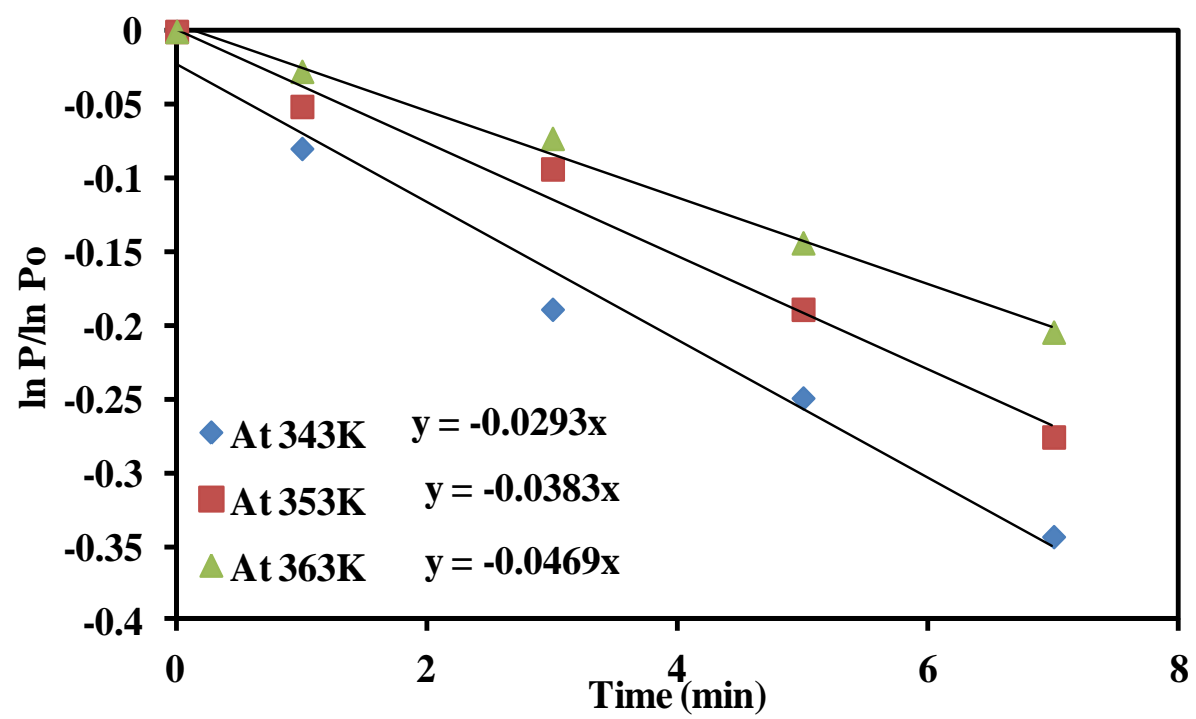

Figure 4. First-order kinetics model of total polyphenol content of amaranth leaves puree at 70,80 , and $90^{\circ} \mathrm{C}$.

\section{Conclusions}

At varied blanching times, the effects of blanching on physicochemical attributes, chlorophyll degradation rate, antioxidants, and total phenolic content of ATP were investigated. In this study, degradation of chlorophyll followed $1^{\text {st }}$ order kinetics, with activation energies ranging from 6.57 to $96.00 \mathrm{~kJ} / \mathrm{mol}$. Also, the value of TPC and TAA in Amaranthus leaves puree decreased as the blanching time increased. The first-order kinetic model was shown to be the most appropriate model for representing the degradation of total antioxidant activity and phenolic content of ATP during blanching at various time intervals. According to our findings, using less blanching time to prevent TPC, TAA, and chlorophyll loss is advised. We found that evaluating the effects of blanching duration on ATP antioxidant activity is important in performing a dietary survey, planning intake, and recommending food processing procedures to preserve the most functional and bioactive components in vegetables. 


\section{References}

Akindahunsi, A., Oboh, G. 2004. Change in ascorbic acid, total phenol and antioxidant activity of sun-dried cormonly consumed vegetables in Nigeria. Nutrition and Health, 18, 29-36.

Armon, D. 1949. Copper enzymes in isolated chloroplast. Plant Physiology, 24, 1-15.

Bernhardt, S., Schlich, E. 2006. Impact of different cooking methods on food quality: Retention of lipophilic vitamins in fresh and frozen vegetables. Journal of Food Engineering, 77, 327-333.

Cieślik, E., Leszczyńska, T., Filipiak-Florkiewicz, A., Sikora, E., Pisulewski, P.M. 2007. Effects of some technological processes on glucosinolate contents in cruciferous vegetables. Food Chemistry, 105, 976-981.

del Pilar Ramírez-Anaya, J., Samaniego-Sánchez, C., Castañeda-Saucedo, M.C., VillalónMir, M., de la Serrana, H.L.-G. 2015. Phenols and the antioxidant capacity of Mediterranean vegetables prepared with extra virgin olive oil using different domestic cooking techniques. Food Chemistry, 188, 430-438.

Howard, L., Wong, A., Perry, A., Klein, B. 1999. $\beta$-Carotene and ascorbic acid retention in fresh and processed vegetables. Journal of Food Science, 64, 929-936.

Igbokwe, P. E., Hollins, S. 2000. Response of vegetable amaranth to plant spacing. Journal of Vegetable Crop Production, 6, 75-85.

Ihl, M., Monsalves, M., Bifani, V. 1998. Chlorophyllase inactivation as a measure of blanching efficacy and colour retention of artichokes (Cynara scolymus L.). LWT-Food Science and Technology, 31, 50-56.

Jaiswal, A.K., Gupta, S., Abu-Ghannam, N. 2012. Kinetic evaluation of colour, texture, polyphenols and antioxidant capacity of Irish York cabbage after blanching treatment. Food Chemistry, 131, 63-72.

Jinasena, M., Amarasinghe, A., Amarasinghe, B., Prashantha, M. 2016. Extraction and degradation of chlorophyll $\mathrm{a}$ and $\mathrm{b}$ from Alternanthera sessilis. Journal of the National Science Foundation of Sri Lanka, 44, 11 - 21.

Kao, F.-J., Chiu, Y.-S., Chiang, W.-D. 2014. Effect of water cooking on antioxidant capacity of carotenoid-rich vegetables in Taiwan. Journal of Food and Drug Analysis, 22, 202-209.

Koca, N., Karadeniz, F., Burdurlu, H.S. 2007. Effect of pH on chlorophyll degradation and colour loss in blanched green peas. Food Chemistry, 100, 609-615.

Magazù, S., Migliardo, F., Telling, M. 2008. Structural and dynamical properties of water in sugar mixtures. Food Chemistry, 106, 1460-1466.

Manohar, B., Ramakrishna, P., Udayasankar, K. 1991. Some physical properties of tamarind (Tamarindus indica L.) juice concentrates. Journal of Food Engineering, 13, 241-258.

Manzi, P., Aguzzi, A., Pizzoferrato, L. 2001. Nutritional value of mushrooms widely consumed in Italy. Food Chemistry, 73, 321-325.

Maundu, P. 1996. Utilization and conservation status of wild food plants in Kenya. In The biodiversity of African plants Springer, pp. 678-683.

Musa, N.M., Ibrahim, M., Yakubu, S., Mohammed, U.A., Joel, A.S. 2017. Kinetic modelling of vitamin $\mathrm{C}$ degradation in leafy vegetables during blanching. Chemical and Biomolecular Engineering, 2, 173-179.

Nakilcioglu-Taş, E., Otleş, S. 2017. Degradation kinetics of bioactive compounds and antioxidant capacity of Brussels sprouts during microwave processing. International Journal of Food Properties, 20, S2798-S2809. 
Oboh, G. 2005. Effect of blanching on the antioxidant properties of some tropical green leafy vegetables. LWT-Food Science and Technology, 38, 513-517.

Opazo-Navarrete, M., Tabilo-Munizaga, G., Vega-Gálvez, A., Miranda, M., Pérez-Won, M. 2012. Effects of high hydrostatic pressure (HHP) on the rheological properties of Aloe vera suspensions (Aloe barbadensis Miller). Innovative Food Science \& Emerging Technologies, 16, 243-250.

Oyetade, O., Oyeleke, G., Adegoke, B., Akintunde, A. 2012. Stability studies on ascorbic acid (vitamin C) from different sources. Journal of Applied Chemistry, 2, 20-24.

Palermo, M., Pellegrini, N., Fogliano, V. 2014. The effect of cooking on the phytochemical content of vegetables. Journal of the Science of Food and Agriculture, 94, 1057-1070.

Patil, B., Kshirsagar, R., Sawate, A., Agarkar, B., Zubair, S. 2020. Studies on effects of cabinet dying on functional and phyto-chemical quality of green leafy vegetables powder. Journal of Pharmacognosy and Phytochemistry, 9, 3197-3202.

Puupponen- Pimiä, R., Häkkinen, S.T., Aarni, M., Suortti, T., Lampi, A.M., Eurola, M., Piironen, V., Nuutila, A.M., Oksman- Caldentey, K.M. 2003. Blanching and longterm freezing affect various bioactive compounds of vegetables in different ways. Journal of the Science of Food and Agriculture, 83, 1389-1402.

Rudra, S.G., Sarkar, B., Shivhare, U. 2008. Thermal degradation kinetics of chlorophyll in pureed coriander leaves. Food and Bioprocess Technology, 1, 91-99.

Schwartz, S., Von Elbe, J. 1983. Kinetics of chlorophyll degradation to pyropheophytin in vegetables. Journal of Food Science, 48, 1303-1306.

Wawire, M., Oey, I., Mathooko, F.M., Njoroge, C.K., Shitanda, D., Hendrickx, M. 2016. Kinetics of thermal inactivation of peroxidase and color degradation of African cowpea (Vigna unguiculata) leaves. Journal of Food Science, 81, E56-E64.

Yağcı, S., Göğ̈̈ş, F. 2008. Response surface methodology for evaluation of physical and functional properties of extruded snack foods developed from food-by-products. Journal of Food Engineering, 86, 122-132.

Zhang, J., Satterfield, M.B., Brodbelt, J.S., Britz, S.J., Clevidence, B., Novotny, J.A. 2003. Structural characterization and detection of kale flavonoids by electrospray ionization mass spectrometry. Analytical Chemistry, 75, 6401-6407. 